\title{
Management to Insulate Ecosystem Services from the Effects of Catchment Development
}

\author{
Peter Gell ${ }^{1, *}$ \\ ${ }^{1}$ Wetlands Research Network, Federation University Australia, Mt Helen, Vic. - Australia
}

\begin{abstract}
Natural ecosystems provide amenity to human populations in the form of ecosystem services. These services are grouped into four broad categories: provisioning - food and water production; regulating - control of climate and disease; supporting - crop pollination; and cultural - spiritual and recreational benefits. Aquatic systems provide considerable service through the provision of potable water, fisheries and aquaculture production, nutrient mitigation and the psychological benefits that accrue from the aesthetic amenity provided from lakes, rivers and other wetlands. Further, littoral and riparian ecosystems, and aquifers, protect human communities from sea level encroachment, and tidal and river flooding. Catchment and water development provides critical resources for human consumption. Where these provisioning services are prioritized over others, the level and quality of production may be impacted. Further, the benefits from these provisioning services comes with the opportunity cost of diminishing regulating, supporting and cultural services. This imbalance flags concerns for humanity as it exceeds recognised safe operating spaces. These concepts are explored by reference to long term records of change in some of the world's largest river catchments and lessons are drawn that may enable other communities to consider the balance of ecosystems services in natural resource management.
\end{abstract}

\section{Introduction}

Human societies have reaped food, water and materials from river catchments. While climate variability at a range of time scales has mediated the supply of these resources at regional scales, the sedentarisation of human communities through the Holocene, and the attendant increases in population and technology, has increased the intensity of resource exploitation. The Millennium Ecosystem Assessment reveals the further amplification of impacts of human resource exploitation from the mid$20^{\text {th }}$ century identifying the Great Acceleration, which has prompted calls for the demarcation of a new geological epoch, The Anthropocene [1,2].

While ethical arguments can be mounted that natural systems warrant conservation for intrinsic reasons, the Ecosystem Services they provide humans is increasingly being used to justify investment in wise management [3]. It is recognised that the demand for consumptive resources such as food, water, energy, timber and minerals for the construction of shelter and fibre for clothing is impacting negatively on the other services provided humanity by the natural environment. In market based economies there remain opportunities for the price of consumption to reflect merely the cost of production, with little requirement for it to reflect the trade-off in the loss of assets and services, that are valuable, but represent a challenge to quantify economically. Without full cost accounting of the tradeoffs between services society risks undermining the support afforded by the less quantifiable phenomena and, ultimately, the ongoing supply of provisioning services.

The most readily identifiable services provided by natural ecosystems are usually those that provide directly for human needs. These Provisioning Services comprise potable water and food, including those harvested directly such as fish and native fruit, as well as those sown by people such as crops and stock raised for milk and meat. As a resource timber was used by early hominids as an energy source and then for shelter as technology became more sophisticated. Extracted minerals have replaced timber as a provider of shelter and this fibre is now directed in large volumes to the creation of paper. Most of humanity's energy is now provided by extracted fossil fuels that were largely unavailable before the industrial revolution.

The natural environment also affords considerable benefit to humanity by means that are not defined as provisioning. Natural systems regulate the habitat used by people by moderating microclimatic extremes (e.g. shade, shelter) and by controlling irruptions of pests, predators and disease carrying organisms that may impact negatively on people. It may also mitigate the risk of environmental hazards - coastal and riparian vegetation play's a clear role in protecting human settlements from floods and, as witnessed in 2004, tsunamis. Natural ecosystems also provide support to society that underpins the provision of food and water through the pollination of flowers that beget seed and fruit and the purification of water to mitigate the

* Corresponding author:p.gell@,federation.edu.au 
personal health of consumers. Lastly, nature provides considerable cultural benefits and there is an increasing body of evidence that reveals the wellbeing benefits that accrue from close association with natural systems such as wetlands [4].

From even before the Brudtland Report Our Common Future global ecosystem assessments have revealed, with increasing sophistication and accuracy, the degree to which provisioning services have been exploited at the expense of regulating, supporting and cultural services [5]. The rapid increase in the rate of human impact from the mid $19^{\text {th }}$ century is identified as the Great Acceleration with global scale surveillance revealing exponential increases in human population; and in rates of overfishing, deforestation, water catchment regulation, desertification etc. Variations in socio-political circumstances has yielded spatial variations in these patterns but, for example, China has developed very rapidly and its ecosystems have suffered accordingly, joining the developed world in threatening, and in some circumstances, exceeding safe operating spaces for humanity $[6,7]$.

Long term evidence, however, reveals that humanity has a long history of exploiting its water catchments and impacting on aquatic ecosystems [8]. The development of agriculture and mineral extraction industries is associated with nutrient, metal and sediment pollution as well as salinisation from the mid- to late Holocene. The mere increase in populations in settlements, in the absence of waste management infrastructure, in the $19^{\text {th }}$ century was sufficient to drive the eutrophication of receiving waters and widespread and unprecedented anoxia in the world's deep lakes [9]. So, the trade-off in ecosystem services by human populations has a considerable history [10]. To understand the challenge of restoring the regulating, supporting and cultural services afforded by ecosystems it is important to understand the threats emerging from new technology but also the momentum of ecosystem degradation that is the legacy of human exploitation of provisioning services over millennia.

\section{The Murray Darling Basin}

Many of the world's water resource catchments have come under considerable pressure from land and water development for human consumption. In Australia the Murray Darling Basin (MDB), the continent's largest catchment, represents a case study that reflects clearly the trade-off between services over time [11]. Colonisation of the continent by non-indigenous peoples was relatively late and so the technology brought by the colonists was relatively sophisticated. Further the catchment lies in a spatially and temporally variable climate with low catchment efficiency exposing it to the risks of water resource development. Further, the floodplain soils carry high loads of native phosphorus and are highly erodible, and in many parts, overly saline water tables. In combination these boundary conditions conspired to lead to a rapid degradation of natural resources to provide for an expanding, consumption intensive society. The management of the MDB today represents Australia's greatest environmental restoration challenge with considerable funds directly towards the MDB Plan [12].

Humans have lived in the MDB for at least 46,000 years [13] over which time hydroclimates have changed greatly $[13,14]$. The hydrogeomorphology of the rivers stabilised from $\sim 12,000$ years ago and many wetlands evolved from $\sim 5,000$ years ago as their meandering habit became entrenched. Human populations likely increased from this time as climate, and so resources, became more reliable. Over the millennia preceding European colonisation traditional resource use comprised the harvesting of wildlife and aquatic plants. While people buried foods to render them safe to consume, and sowed tubers to harvest at a later time, agriculture was limited, although plants collected typically represented the largest part of the economy. Ecosystems provided timber for fuel, weapons and water craft and clean drinking water. Floodplain vegetation provided shade and shelter and communities had strong cultural associations with freshwater systems and their biota.

The MDB was a focus for exploration soon after the colonisation of the continent by Europeans and settlements were established within the catchment from the early-to-mid-1800s. Very soon after settlement the plains supported large numbers of stock run for wool and food. Intensive gold mining in the watershed from 1848 and the extraction of water for irrigation agriculture, most from 1880, added to the destabilisation of the landscape. The state parliament in Adelaide, near the base of the Basin, first discussed the threat of water use in the upper reaches as early as 1887 and the Interstate Royal Commission into the basin testified to eutrophic river waters impacted by mining sludge [15]. Soldier settlement schemes following the two world wars promoted land clearance and accelerated river regulation and water consumption which ultimately drew saline water tables to the surface driving widespread dryland and wetland salinisation, particularly after the wet La Nina phases in the 1950s and 1970s [16]. While cyanobacterial blooms were recognised from 1878 [17] the Darling River suffered an unprecedented bloom of over $1000 \mathrm{~km}$ in length in 1991; a risk that remains for most surface waters in the southern basin. To turn this Basin in the nation's food bowl, provided in excess of $40 \%$ of its agricultural gross domestic product, most land is now cleared, the native fishery is greatly diminished, resilience to climate variability has been compromised and natural systems have suffered from the increasing flux of salts, sediments and nutrients [18] to the point where the basin is regarded as one of ten Australian ecosystems most at risk of exceeding a tipping point [19].

While there has long been concern on the state of the MDB waterways, the first comprehensive assessments came in the $21^{\text {st }}$ century, mostly associated with the call to provide river flows to restore ecosystems. The Sustainable Rivers Audit [20] and other commissioned reports revealed the Basin to be widely 
degraded and the waters over-exploited for the provision of irrigation agriculture to produce food and fibre. This drew contest from those with a water allocation and this escalated into a politicised debate over water volume. The emerging Water Act (2007) provided for the Murray Darling Basin Plan which released \$13B AUD to recover 3200 GL $(\sim 25 \%)$ of mean annual flow to restore the aquatic ecosystems of the Basin. This modern debate over water volume overlooked the long recognised impact of catchment disturbance on the services afforded both people and ecosystems.

\section{Long Term Change}

In 1917 Australia embarked on a program of river regulation and commissioned a suite of weirs along the River Murray and other MDB tributaries from 1922 to 1936. Consistent with the accelerated development of water resources in the northern hemisphere the construction of large dams from the 1950s lead to significant, additional river regulation. In the absence of water quality monitoring or biological assessments water diversions and reduced flows became identified as the principal driver of ecosystem decline. In particular, the terminal lakes, deemed to be predominantly fresh [21] but estuarine elsewhere [15] were considered to be at risk of salinisation through inundation by seawater owing to the diminished freshwater flows [22]. This dissonance of view highlights the opacity of evidence derived from historical sources. Clear evidence of past condition is highly instructive in terms of scoping options for restoration, but also in understanding the trade-offs between various ecosystems services that have occurred under past management eras.

While archaeological sources document the presence of people, and by inference the effect they may have had on the river and its floodplain, artefact are often poorly constrained in time and sites rarely report on the response of the ecosystems. Sediment-based paleolimnological records on the other hand, while not recording directly the presence of people, are usually well dated, are continuous in time and provide detailed inferences as the condition of lentic waterways. Over 50 records of wetland change have been documented across the southern Basin. Several provide evidence of preEuropean baseline conditions and point to long periods of stasis mediated by regional hydroclimatic variation [23]. While the impact of indigenous people on wetlands has not been demonstrated, but is not discounted, substantial and often unprecedented changes occurred from the period when new people, their technologies and stock developed the catchment to provide for a rapidly increasing population. These changes included widespread increase in waterway turbidity, rapid sedimentation of shallow wetlands, eutrophication and salinisation [24], and loss of aquatic plant communities. While most wetlands changed after river regulation, in many instances on account of a regime of more frequent flooding, many impacts are evident from soon after European settlement and are attributable to direct impacts of erosion and the release of pollutants.
A shift from wetlands rich in aquatic plants to systems dominated by phytoplankton was first documented by Ogden [25] and then more widely by Reid et al. [26]. Gell and Reid generated a typology of wetlands vulnerable to this switch attributable to the attenuation of light in the water column with elevated water turbidity [27]. While Ogden showed associated shifts towards pelagic zooplankton; Kattel et al. documented a decline in faunal diversity [28]. The structure of the decline documented from the sediment sequences is consistent with the model of regime shifts or the critical transitions documented for Lake Erhai in Yunnan province by Wang et al., [29]. Given the challenge in demonstrating changes to ecological feedback effects from sediment records, and the unlikelihood of removing the likely stressor of change, it is challenging to demonstrate a regime shift based on the criteria identified by Capon et al. [30]. As such the change may well represent a press response to ongoing sediment and nutrient flux [31]. Critically, the replication of these changes in Murray floodplain wetlands, and the identification of the river channel as a source of sediments [32] leads to the suggestion that the critical transitions are occurring at a sub-basin scale rather than wetland-by-wetland. Irrespective, these records attest to the diminishing capacity to regulate water quality and cultivate the supporting services that provide ecosystem resilience. The heightened contest over water resources reveals that society is recognising the decline in cultural services once afforded by the biodiversity rich wetlands.

\section{Recovery - The Basin Plan}

The Australian and relevant State Governments implemented The Murray Darling Basin Plan that is to invest in the purchase of water allocation licenses and water delivery infrastructure to recover $2750 \mathrm{GL}$ of irrigation allocation for use in environmental flow programs across the Basin. The intent is to allocate a supplementary 450 GL if it can be demonstrated that this will have little negative impact on regional communities. This Plan reveals that Australian society has accepted that the provisioning services made possible through the regulation and diversion of the Basin's water for agriculture have been at the expense of other services, and the intrinsic value of the natural aquatic ecosystems. It does, however, identify water volume as the principal cause of this decline, possible as water over allocation can be readily rectified using economic mechanisms whereas water quality issues cannot. A Long Term Intervention Monitoring program has been implemented to assess the ecological recovery from the release of environmental water. Yet, as with any monitoring program, the perceived success or otherwise can be influenced by the selected baseline against which recovery is assessed. Clearly, assessing performance against decade old monitoring, rather than paleoecological records that can report on pre-regulation, and even pre-industrial conditions, will paint the restoration success in a brighter light. 
Meanwhile, the decision to implement the Plan brought an abrupt impact to food and fibre producers who were encouraged to forego water allocation. Having been encouraged by past governments to develop irrigation plots through settlement schemes this generation of growers have been required to adapt abruptly to a withdrawal of water in a rapid switch to a management regime that values other services provided by the same water. The implementation has been abrupt and, likely owing to poor socio-economic assessment and modelling, measures to moderate the impacts are being implemented retrospectively. The reaction to the Plan has been acute having pitted growers against the authorities and rural interests against urban. This prompted a Federal Senate Select Inquiry into the Basin Plan in 2015 where communities were pitted against each other in making their case for access to water. Now, a Royal Commission has been called by the South Australian Government to investigate impediments to the provision of what they perceive to be their right to water.

\section{Balancing Ecosystem Services}

The degraded state of the Murray Darling Basin and the fraught nature of the political contest over critical water resources are clear symptoms of the prioritisation of provisioning services. While the South Australian Parliament were debating the impact of upstream water use on the water that flowed into their jurisdiction as early as 1887 there has been a state sanctioned drive to use Basin water to provide food and fibre for domestic and overseas markets for more than a century since. Over this time there has been little attention paid to the regulating, supporting or cultural services provided by the same water. This has left the landscape and communities more vulnerable to climate change which is forecast to lead to lower rainfall and runoff. The legacy of the narrow focus on provision is the substantial direct cost of the Plan - \$13B and the inestimable indirect costs to communities, so this demands much economic readjustment to repair these other services. These include reinstating the heavily impacted community cohesion; the risk to wellbeing of rural communities and the endangered natural biodiversity. Even so, given the compromised quality of the water to be allocated to the environment, it appears unlikely even this investment will address issues of turbidity, sedimentation and eutrophication to allow for complete recovery. There remains a risk that thresholds exist whereupon regulating services become permanently diminished or the cost of recovering them is prohibitive.

Clearly, had those advocating so enthusiastically for catchment development over a century ago had the foresight to value other services as much as they did provisioning, then the system resilience would not have become so compromised. Clearly it would have been better to have adapted through time and empowered the community to produce food and fibre, but also protect the natural systems and the benefits that accrue from them and to be prepared for unforeseen circumstances. While the time has passed to avoid many of the consequences of overexploitation, it is essential to implement adaptation now, as the Plan intends, to avoid the need for transformational change [33]. A just approach may be to distribute the cost of the implementation of an adaptation cycle across multiple generations in an adaptation pathways approach [34] rather than levelling the full cost on today's providers. The degraded state of the Murray Darling Basin serves as a lesson of overexploiting the provisioning services of natural systems. Davis et al. (2016) observe that Australia would do well to apply the lessons of the MDB crisis should it seek to develop the landscape in the tropical North.

Globally, developing countries would do well to apply the same lessons. The modern condition of the Semarang River reflects a similar enthusiasm for the development of provisioning services in the form of agriculture. This is likely an outcome of the necessity for providing for an increasing regional population and the primacy of food provision as a socio-economic necessity. Here, steep landscapes have been cleared of rainforest and terraced, lakes impounded and water flow regulated to service market gardens. To maximise production nutrients have been added and these are carried in return waters to river tributaries. The opportunity cost of this is the degradation of the waterways and the loss of this resource at a potable water supply. In Melbourne early planners protected the water catchments and still today, the supply of water to Melbourne is drawn from forested catchments ensuring that the surface waters remain the principal source of potable. The compromised quality of the potable water of Semarang leaves authorities with the choice of importing water or extracting groundwater. The modern focus on groundwater is an expensive solution which fails to address the driver of the problem - waterway management in the upper catchment. Often groundwater resources are not recharged at the rate water is abstracted and so groundwater based solutions to water provision are often unsustainable in the long term. Further, groundwater plays a critical role in landscape stability and unsustainable extraction of groundwater can lead to land subsidence, coastal inundation and diminished regulating services in coastal settings.

In both the MDB and the Semarang River the adoption of an holistic ecosystem services approach at the outset may have avoided the trade-offs between services and the level of degradation experienced today. Now realising that degradation and the diminished amenity the challenge to recover ground and adopt a more sustainable path is expensive and challenging. While short political cycles and discount rates act to encourage governments to differ expensive measures that may mitigate overexploitation of natural resources, intergenerational equity demands that society mitigates the decline in services at the same time as it reaps the benefits of harnessing the provisioning services of its natural ecosystems. 


\section{References}

1. Millennium Ecosystem Assessment. Millennium Ecosystem Assessment Findings. Millennium Ecosystem Assessment. (2005)

2. Steffen, W., Crutzen, P.J. \& McNeill, J.R. Ambio, 36 : 614-621. (2007)

3. Costanza, R., d'Arge, R., de Groot, R., Farber, S., Grasso, M., Hannon, B., Limburg, K., Naeem, S., O’Neill, R.V., Paruelo, J., Raskin, R.G., Sutton, P. \& van den Belt, M. Nature, 387 : 253-260. (1997)

4. Finlayson, C.M., Horwitz, P. \& Weinstein, P. Wetlands: Ecology, Conservation and Management, volume 5. Springer, Dordrecht, 263 pp. (2015)

5. WCED. Our Common Future. OUP. 383pp. (1987)

6. Rockström, J., Steffen, W. ., Noone, K., Persson, A., Chapin III, F.S., Lambin, E., Lenton, T.M., Scheffer, M., Folke, C., Schellnhuber, H., Nykvist, B., De Wit, C.A., Hughes, T., van der Leeuw, S., Rodhe, H., Sörlin, S., Snyder, P.K., Costanza, R., Svedin, U., Falkenmark, M., Karlberg, L., Corell, R.W., Fabry, V.J., Hansen, J., Walker, B., Liverman, D., Richardson, K., Crutzen, P., Foley, J. Nature, 46: 472-475. (2009)

7. Dearing, J.A., Wang, R., Zhang, K., Dyke, J.G., Haberl, H., Sarwar Hossain, Md., Langson, P.G., Lenton, T.M., Raworth, K., Brown, S., Cartstensen, J., Cole, M.J., Cornell, S.E., Dawson, T.P., Doncaster, C.P., Eigenbrod, F., Flörke, M., Jeffers, E., Mackay, A.W., Nykvist, B. \& Poppy, G.M. Global Environmental Change, 28: 227-238. (2014)

8. Dubois, N., Saulnier-Talbot, E., Mills, K., Gell, P., Battarbee, R., Bennion, H., Chawchai, S., Dong, X., Francus, P., Flower, R., Gomes, D.F., GregoryEaves, I., Humane, S., Kattel, G., Jenny, J-P., Langdon, P., Massaferro, J., McGowan, S., Mikomägi, A., Ngoc, N.T.M., Ratnayake, A.S., Reid, M., Rose, N., Saros, J., Schillereff, D., Tolotti, M. and Valero-Garcés, B. First human impacts and responses of aquatic systems: A review of palaeolimnological records from around the world. The Anthropocene Review. (2017)

9. Jenny, J-P., Francus, P., Normadeau, A., Lapointe, F., Perga, M-E., Ojala, A., Schemmelmann, A. and Zolitschka, B. Global spread of hypoxia in freshwater ecosystems during the last three centuries caused by rising local human pressure. Global Change Biology, doi: 10.1111/gcb.13193. (2016)

10. Dearing, J.A., Yang, X., Dong, X., Zhang, E., Chen, X., Langdon, P.G., Zhang, K., Zhang, W. and Dawson, T.P. Extending the timescale and range of ecosystem services through paleoenvironmental analyses, exemplified in the lower Yangtze basin. Proceedings of the National Academy of Sciences, US 109: E1111-1120. (2012)

11. Davis, J.A., O'Grady, A.P., Dale, A., Arthington, A.H., Gell, P., Driver, P., Bond, N., Casanova, M., Finlayson, M., Watts, R., Capon, S., Nagelkerken, I., Tingley, R., Fry, B., Page, T.J., Specht, A. When trends collide: the challenge of protecting freshwater ecosystems under multiple land use and hydrological intensification scenarios. Science of the Total Environment. doi: 10.1016/j.scitotenc.2015.03.127 (2016)

12. Murray Darling Basin Authority. MDBA Basin Plan. MDBA, Canberra. (2013)

13. Bowler, J.M., Johnstone, H., Olley, J.M., Prescott, J.R., Roberts, R.G., Shawcross, W.F., \& Spooner, N.A. Nature, 421 : 837-840. (2003)

14. Mills, K., Gell, P., Hesse, P.P., Jones, R., Kershaw, P., Drysdale, R. \& McDonald, J. Australian Journal of Earth Sciences, 60, 547-560. (2013)

15. Davis, J., Murray, S. and Burchell, F.N. Interstate Royal Commission on the River Murray, representing the states of New South Wales, Victoria, and South Australia: report of the Commissioners with Minutes of evidence, appendices, and plans. Parliament of Victoria, Melbourne. (1902)

16. Macumber P. Interaction between groundwater and surface systems in northern Victoria. Department of Conservation and Environment,Victoria, Melbourne. (1991)

17. Francis, G. Nature, 2: 11-12. (1878)

18. Gell, P., Fluin, J., Tibby, J., Hancock, G., Harrison, J., Zawadzki, A., Haynes, D., Khanum, S., Little, F. \& Walsh, B. Geomorphology, 108: 122-126. (2009)

19. Laurance, W.F., Dell, B., Turton, S.M., Lawes, M.J., Hutley, L.B., McCallum, H., Dale, P., Bird, M., Hardy, G., Prideaux, G., Gawne, B., McMahon, C.R., Yu, R., Hero, J-M., Schwarzkopf, L., Krockenburger, A., Douglas, M., Silvester, E., Mahony, M., Vella, K., Saikia, U., Wahren, C-H., $\mathrm{Xu}$, Z., Smith, B. \& Cocklin, C. Biological Conservation, 144: 1472-1480. (2011)

20. Davies, P.E., Harris, J.H., Hillman, T.J. \& Walker, K.F. Marine and Freshwater Research, 61: 764777. (2010)

21. Sim, T. and Muller, K. A Fresh History of the Lakes: Wellington to Murray Mouth, 1800s to 1935. River Murray Catchment Water Management Board, Strathalbyn: 75pp. (2004)

22. Gell, P.A. Watching the Tide Roll Away Advocacy and the Obfuscation of Evidence. Pacific Conservation Biology. (2018)

23. Gell, P., Bulpin, S., Wallbrink, P., Bickford, S. \& Hancock, G. Marine and Freshwater Research 56: 441-456. (2005)

24. Gell, P. \& Reid, M. The Anthropocene, 8: 39-45. (2014)

25. Ogden, R.W. Regulated Rivers: Research \& Management 16: 497-512. (2000)

26. Reid, M.A., Sayer, C.D., Kershaw, A.P. \& Heijnis, H. Journal of Paleolimnology 38: 191-208. (2007)

27. Gell, P. and Reid, M. Frontiers in Ecology and Evolution, 4, 16. (2016)

28. Kattel, G., Gell, P., Perga, M., Jeppesen, E., Grundell, R., Weller, S., Zawadzki, A. \& Barry, L. Freshwater Biology 60(4): 711-723. (2014)

29. Wang, R., Dearing, J. A., Langdon, P. G., Zhang, 
E., Yang, X., Dakos, V. and Scheffer, M. Nature, 492, 419-422. (2012)

30. Capon, S.J., Lynch, J.J., Bond, N., Chessman, B.C., Davis, J., Davison, N., Finlayson, C.M., Gell, P.A., Hohnberg, D., Humphrey, C., Kingsford, R.T., Nielsen, D., Thomson, J.R., Ward, K. and MacNally, R. Science of the Total Environment, 534, 122-130. (2015)

31. Kattel, G., Gell, P., Zawadzki, A. \& Barry, L. Hydrobiologia 787(1): 269-290. (2017)

32. Grundell, R., Gell, P., Zawadzki, A. \& Mills, K. Journal of Paleolimnology. 47: 205-219. (2012)
33. Walker, B. \& Salt, D. Resilience Thinking: Sustaining Ecosystems and People in a Changing World. Island Press, Washington, DC. (2006)

34. Butler, J.R.A., Suadnya, W., Yanuartati, Y., Meharg, S., Wise, R.M., Sutaryone, Y., and Duggan, K. Priming adaptation pathways through adaptive -co-management: Design and evaluation for developing countries. Climate Risk Managememnt, 12: 1-16. (2016) 